\title{
Migdal's Theory of the State-in-Society in the Context of Sri Lanka: A Critical Review
}

\author{
Mansoor Mohamed Fazil \\ Department of Political Science, \\ Faculty of Arts and Culture, \\ South Eastern University of Sri Lanka, \\ University Park, Oluvil, Sri Lanka
}

Doi: 10.36941/ajis-2019-0027

\begin{abstract}
This study analyses state-minority contestations for power and domination in Sri Lanka. The study also reviews the process of state formation and the attempts at state reconstitution with the intention of shedding light on the centralised unitary nature of the state that has prevailed during the post-colonial period. This assessment provides insights into the character of the present state-in-society approach, if such a distinct approach exists, and determines why this new approach is critical in the context of Sri Lanka. The study is a qualitative analysis based on text analysis. The study makes two major contributions, achieved by extending the state-in-society theory to cover the two aspects, 'militant social forces' and 'post-civil war state and society'. The first contribution is to expand the state-in-society theory by including a strong militant group as a social force, which was excluded in Migdal's approach. The second contribution is to expand the state-in-society theory to study post-war state and society transformation and how they reconstitute each other. Both contributions are highlighted in the paper.
\end{abstract}

Keywords: civil war, contestations, militant, society, state

\section{Introduction}

As is common with other schools of thought, the state-in-society approach has its own unique terminology. This approach was developed from Migdal's scholarly works, specifically from his book on state-in-society; this book examines how states and societies transform and constitute one another (2001a). The central conceptual argument of Migdal's approach suggests a definition of the state that differs from the concept of Max Weber, because the former interprets the definition in two parts. According to Migdal (2001a, pp. 15-16), the state is a field of power that can use or threaten to use violence and is shaped by (1) the image of a coherent and controlling organisation in a territory, which is a representation of the people bounded by that territory, and (2) the actual practices of its multiple parts. This definition is structured around the practices and image of the state platforms and is 'the core analytical and methodological' principle that runs through and defines state-in-society scholarship (White, 2013).

The state-in-society approach, focusing on the state-in-society during state engagement with other social forces, highlights the mutual transformation of the state and other social groups (Migdal, 2001a). This approach mainly studies the relationship between the state and society. In the context of Sri Lanka, the nature of this relationship took a different form after independence. Accordingly, the larger segment of the society (Sinhalese) constituted a part of the unitary state, whereas the Tamil minority were excluded from the state structure through discriminatory policies. Migdal failed to provide adequate insight into this nature of the state and this pattern of formation of 
society. The state-in-society approach emphasises social forces as representing society, a factor that ensures a powerful mechanism for associative behaviours. These forces encompass informal organisations, such as Senegal's patron-client networks or friendship groups and old-boy networks in other societies, as well as formal organisations, such as businesses and churches (Migdal, 1994, 1998, 2001a). In the state-in-society approach, powerful social militant movements, such as the Liberation Tigers of Tamil Eelam (LTTE), are not considered as a social force. The state-in-society approach presented by Migdal has to be expanded to fit the context of Sri Lanka in order to examine the formation, structure, and influence of the LTTE, a powerful and well-equipped (Nieto, 2008; Flynn, 2011) social force with a strong international network that represented the Tamil minority. This political group differs from the social forces indicated by Migdal as capable of changing state-society relations. In fact, the institutions mentioned in his approach are not as powerful and influential as the LTTE proved to be. Given this gap in Migdal's approach, the present study provides brief insights into the formation and eventual defeat of this militant social force.

\section{Methodology}

This research is a qualitative analysis that is based on text analysis and limited observation. The data collection was done based on a desk studyl literature survey, which included all the material available on the subject of state, post-colonial state formation, especially in Sri Lanka, attempts and opportunity for state reconstitution, and current leading post-war discourses on issues in Sri Lanka such as difficulties in state reconstitution and other aspects such as the desire of state and society for power and domination. All these were reviewed carefully by the author. Further, information was also collected from books, previously conducted research and reports, journals, government publications, media articles and additional relevant documents. The qualitative field study was conducted using observation method in different locations of the study areas. Researcher is a Sri Lankan national, a native of a former conflict affected area (Eastern Province). To engage in direct observation, the researcher was required to be in the field several times. Therefore, he was in the field over three times for data collection and once for the purpose of observation. The research was designed and carried out using a critical and interpretative approach, originating from critical theory and constructivism. This approach is more suitable for critical study and understanding of the statein-society theory with its application in the context of Sri Lanka.

\section{Brief Account of the Image and Practices of the State of Sri Lanka}

The image of the post-colonial majoritarian unitary state of Sri Lanka was sufficiently dominant to control all the rule-making processes instrumental to the social control within its territory. In this regard, state policies were formulated and implemented to safeguard and satisfy the Sinhalese majority and aimed at obtaining their electoral support for the mainstream UNP and SLFP political parties whilst discriminating against the Tamil speaking minorities. Some leading policies of this type were the Citizenship Act, the 'Sinhala Only' language Act, land policies, university admission and employment policies. In view of these circumstances the Tamil minorities, who felt they were being alienated from the body politic with their culture being neglected, challenged the Island's post-colonial trajectory. In this way, a state-minority contestation developed in Sri Lanka.

In practice, the citizenship of Indian Tamils and Pakistanis was revoked by the state of Sri Lanka, rendering them stateless. Through the Ceylon Citizenship Act no. 18 of 1948 and the Indian and Pakistani Residents (Citizenship) Act of 1949, the minority Estate Tamil population of Sri Lanka were stripped of their citizenship and voting rights. These Acts made it constitutional for Indian Tamils to be excluded from participating in the political and economic spheres of their country. Thus, by this legislative enactment, the image and practice of the state had reduced the Tamils' political strength and rights to a farce (Rabushka \& Shepsle, 1972). This law denied the Indian Tamils their political rights so they could not send anyone to represent them at the parliamentary 
elections held in the years 1952, 1956, 1960, 1965, and 1970.

Bandaranaike ${ }^{1}$, the former Prime Minister, strategically used the policy of marginalising the colonial English language as a supportive base for his electoral victory in 1956 (Bandarage, 2010). "In 1956, while discontent with the UNP grew, Bandaranaike was able to tap into Buddhist religious fervour as the country celebrated the two thousand five hundredth year anniversary of the Buddha's death to restore the Island's historical legacy as the Sihaladipa (Island of the Sinhalese) and Dhammadipa (Island of the Buddha's teachings)" (De Silva, K.M., 1981, p. 517, as cited in Bandarage, 2010). The growing Buddhist social force was established to address the rising social and economic apprehensions in the rural areas of the country (Halliday, 1975). Bandaranaike's SLFP and politicised Sinhala Buddhist forces formed a coalition - the People's United Front (Mahajana Eksath Peramuna [MEP]) - to win the 1956 general election. MEP's foremost electoral campaign promise and manifesto was to make Sinhala the National Language within 24 hours if they came to power. Immediately afterwards, the Official Language Act No. 33 was passed in Parliament, making Sinhala the sole official language, amidst protests by Tamil people and the leftwing parliamentary groups.

When the SLFP promulgated Sinhala as the official language (The Sinhala Only Act), it effectively excluded minorities, including many English-speaking Sinhalese and Burgher communities, as well as Tamils and Tamil speaking Muslims. A turning point in Sri Lankan politics was the 'Sinhala Only' Act of 1956, which made Sinhala the sole official language and thus restricted many government jobs to Sinhala speakers (Heidorn, 2006, p. 06). This disastrous policy triggered the first inter-ethnic riots since independence, with Tamil shops being looted and burnt in Colombo after a peaceful Tamil protest was disrupted by Sinhalese nationalists (ICG, 2006, p. 03). The enactment of the language policy was widely seen as a two-pronged move to reduce the position of Tamils in state services and facilitate the access of the Sinhala-educated persons to prestigious jobs (Abeysekera, 1985, p. 243).

Tamil leaders claimed that the Sinhala language legislation would bring in an era of 'apartheid' with Sinhalese as the 'masters and rulers' and that Tamils would be forced to 'accept subject status under them'. Chelvanayakam argued that in the absence of linguistic parity, Tamils had no alternative but to seek 'Federalism or Separatism'. Even Ponnambalam who was opposed to federalism began to say that the Tamils might need to launch a movement for self-determination ${ }^{2}$ (Kearney, 1967).

This political mistake that was in favour of the majority community was the root cause of ethnic rivalry and its escalation into full-scale war. Efforts were made later to grant the Tamil language equal status with the Sinhala language in the constitution as a compromise to the Tamils, but the state failed to implement this in the service delivery institutions.

In order to fulfil its national development strategy, the Sri Lankan state developed a range of policy measures that benefited the peasantry as a class. Land settlement schemes were introduced by which state-owned land was developed and distributed among the landless peasantry. The first set of policies distributed state-owned land. The second was aimed at reforming tenure arrangements (Bastian, 2009). The Gal Oya Development Scheme was the first major multi-purpose development scheme initiated by the post-independence government. The then Prime Minister D.S. Senanayake inaugurated the scheme, stating that it would provide economic opportunities to the peasants and bring prosperity to both Tamils and Muslims of the Eastern Province.

\footnotetext{
${ }^{1}$ In 1951 Bandaranaike left the UNP owing to the leadership issue and formed the Sri Lanka Freedom Party (SLFP). The new party contested in the 1952 general election but was able to win only a few seats.

${ }_{2}^{2}$ As more and more Sinhalese sought government jobs, they felt that their opportunities were thwarted by prior entrenchment of Tamils in the public service (Vittachi, 1959). Although Sinhalese were about six times more numerous than the Ceylon Tamils, the Ceylon State Service employed nearly half as many Tamils as Sinhalese, and the Judicial Service had two-thirds as many Tamils as Sinhalese in 1946 (Kearney, 1967). In 1962, over 40 percent of the Medical Service, i.e. most doctors were Tamil. Making Sinhala the official language then, was seized upon as a means to improve Sinhala participation and to reduce Tamil (as well as Burgher) entrenchment in the public service. With the switchover of the language movement from Swabhasha to Sinhala Only, the terms of the political conflict shifted from a struggle against English to a struggle against Tamil privilege.
} 
During the 1950s, Tamil nationalists began to criticise peasant settlements in the Dry Zone, especially in the Eastern Province, as a form of state-sponsored encroachment of 'Tamil areas' by the Sinhalese. They alleged that since the benefits of the settlement went largely to the Sinhalese, it constituted a form of state-sponsored 'discrimination' against the Tamils (Peris, 1996, as cited in Bandarage, 2010, p. 47). In January 1956, before the general elections and the passing of the language bill, Chelvanayakam was arguing that the Sinhalese were 'colonising the rich agricultural districts like Gal Oya and Kantalai in the Tamil provinces'3 (Wilson, 1994, as cited in Bandarage, 2010, p. 47).

Further, it can be surmised that the state organised the planned settlement of Sinhalese in the Northern and Eastern provinces where the minorities were predominant, in order to establish and increase the proportion of Sinhalese in those areas. Sinhala political elites succeeded in their intention to increase Sinhala people's representation in all democratic institutions and thus found the way to dominate in the administrative institutions too. It was clearly an attempt to decrease the minorities' domination in their traditional areas of habitation. Thus, the land policy of the state was one of the motivating factors behind the mobilisation of Tamil youths under the call for a separate state (Fazil, 2018). The ostensible objective of the Sinhalese settlements in the Tamil areas was agricultural development, but the hidden objective was to weaken the Tamil's demand for a separate homeland. Owing to an increase in the number of Sinhalese settlements the district boundaries were redrawn and new districts established (Fazil, 2018).

This settlement scheme as well as other government policies greatly contributed to the deterioration of peaceful inter-ethnic relations and fuelled tension, which subsequently led to violence in Sri Lanka.

Further, changes in the university admissions policy contributed substantially and dramatically to the worsening of ethnic relations in Sri Lanka over the last three decades, radicalising the politics of the Tamil areas in the north and east of the Island (De Silva, 2005). As education in Sri Lanka is seen as the primary path to social mobility (especially by the Tamils), restricting university admissions caused them immense frustration (Orjuela, 2004, p. 90). This was a devastating blow to a community that valued education above everything else and saw it as the vehicle of social and economic advancement (Senake, 1985). The issue was caused by the scheme of standardisation that was introduced by the government in the 1970s. Its main aim was to increase the number of Sinhalese youth entering university, and this naturally had the effect of severely reducing the number of Tamil undergraduates due to the limited intake of universities. ${ }^{4}$

\footnotetext{
${ }^{3}$ The unfair distribution of land was formalised by the introduction of new administrative boundaries. During the creation of the new Ampara District in 1962, the Government Agents made sure that administrative mechanisms were geared in such a manner that the lands taken from the Muslims could not be recovered. In addition, administrative boundaries were redrawn to optimise Sinhalese presence. In order to establish a fictitious Sinhalese dominance in the Ampara District, Sinhala settlements in the Batticaloa District were annexed to settlements in Ampara District. In order to fulfil and strengthen the Sinhala domination in the district, the Government intensified development projects that resulted in demographic changes and a gradual growth of ethnic conflict previously unknown in the region. A similar process took place further north in Trincomalee District. There, the Muslims and Tamils possessed land in the areas of Pothana, Kattukachchi and Kantalai. Under the government's planned colonisation - in the guise of yet another 'sugar industry' at Kantalai thousands of acres of paddy lands belonging to Muslims were systematically confiscated and distributed among the Sinhalese. As the 1921 census revealed, the Sinhalese population in Trincomalee district was around 3\%, while in Batticaloa and Ampara Districts their share was less than 5\%. Correspondingly, the total Sinhalese population in the Eastern Province constituted less than 4\%. Sixty years later, the proportion of the Sinhala population in the Eastern Province had grown to 25\%, as was shown by the 1981 census. It is noteworthy that the proportion of the Sinhalese people increased several fold due to the colonisation schemes implemented by the government in the predominantly Tamil and Muslim regions of the East (Fazil, 2004). Among other changes, this resulted in Sinhala majority populations in twelve new Pradeshiya Sabhas and one Municipal Council area.

${ }^{4}$ It was decided to set different 'cut-off points' to regulate the quota of students from each ethnic group. In effect, this meant that students studying in Tamil had to obtain higher marks than their Sinhalese counterparts to enter the science and medical faculties in the country's universities. After protests from academics as well as politicians, the scheme was changed in 1973 to one of 'standardising' the marks (De Silva, C.R., 1997). In the following year 1974, a modification of the scheme was introduced by way of the 'district quota' system.
} 
The Tamils felt that they were openly discriminated against, which led to the alienation and increasing radicalisation of Tamil youth. The Sri Lankan Tamil leadership, which interpreted all developments through a narrow Sinhala versus Tamil lens, agitated against the district quota system, claiming it as a policy of Sinhala state discrimination against Tamils, which operated by eliminating open competition (Bandarage, 2010).

Thus, the image and actual practices of the post-independent state of Sri Lanka amounted to formulating and implementing special policies to satisfy the Sinhala majority peasantry while discriminating against and alienating the Tamil minority by practically excluding it from the state system. In this situation, the Tamil elites prompted the youths to regain their rights through peaceful means by making a demand for federalism and state reconstitution. Nevertheless, the policy of standardisation proved to be a turning point in the history of Tamil political rivalry in that it served to mobilise the educated Tamil youth and drive them towards violent struggle through the formation of militant social forces.

\section{Formation and Defeat of Militant Social Force}

As a result of the policies of exclusion, state and minority contestation began when a demand was made by Tamil minority political elites to amend the unitary constitution of Sri Lanka to allow regional autonomy to the North and East by means of a federal solution. As a result of continuous discrimination and fruitless negotiations since the mid-1970s, Tamil politicians shifted from support for federalism to a demand for a separate Tamil state, namely, 'Tamil Eelam', comprised of the Northern and Eastern provinces of Sri Lanka, which were the traditional areas of Tamil habitation. Other groups, particularly the Liberation Tigers of Tamil Eelam (LTTE) sought to establish an independent state through armed revolt.

The LTTE gradually developed into a strong militant social force and challenged the image and practice of the state of Sri Lanka. Some of the LTTE's military victories over the Sri Lankan state and its ability to control substantial territory in the Northern and Eastern provinces led to a questioning of the state's image at the end of the 20th century; however, neither the state nor the LTTE were fully victorious. The change in international perceptions following the September $11^{\text {th }}$ terrorist attack in the United States of America combined with the stalemate in the civil war in Sri Lanka brought both parties into the negotiation process.

This study argues that to find a solution to these state-minority contestations, attempts were made by the state of Sri Lanka towards a peace settlement with the LTTE, and these had involved some measure of third party or international intervention, including India and later Norway. A new optimism regarding a long-lasting peace emerged when the Norwegian government was invited officially in 2000 by the Government of Sri Lanka as well as the LTTE to facilitate a peace process. Norway helped broker a Memorandum of Understanding/ Cease Fire Agreement (CFA), which was signed by both parties in February 22, 2002.

The key provision in the agreement was a respect for existing frontlines. This initiative left large tracts of territory in the North and East under LTTE control as mentioned in the CFA. ${ }^{5}$ Several important agreements for further development of the peace process were made during six rounds of negotiations. An important outcome of the third round of talks held in Norway was the Oslo Communique, in which both parties agreed to explore "a solution founded on the principle of internal self-determination in areas of historical habitation of the Tamil-speaking peoples based on a 'federal structure' within a united Sri Lanka." This event was interpreted widely as a shift in the LTTE position from 'separatism' to 'self-determination'. Both parties had changed their original demands significantly by moving away from the unitary position of the Sinhalese ruling class and the separatist position of the LTTE. These negotiations faced a major setback when the LTTE suspended its participation after the sixth round of talks. Thus, another important finding of this

\footnotetext{
${ }^{5}$ As stated by Migdal and supported by Toit, the strong state of Sri Lanka was transformed into a 'weak state', whereas the LTTE transformed itself into a strong militant social force with quasi state structure to achieve its goal of Tamil Eelam.
} 
study is that the Norwegian facilitation had not been very successful in bringing peace to Sri Lanka because of new political developments domestically and internationally.

The state-in-society approach also indicates that the state's intrusion leads to the destruction, co-option, or subjugation of local social forces and domination by the state (Migdal, 2001a, 1994). In Sri Lanka, the state intrudes into society and destroys the minority social force, that is, the LTTE. The state penetrated ${ }^{6}$ the LTTE with an alliance of international actors, broke its Eastern wing (headed by Colonel Karuna), formed another social force made up of Karuna's faction and incorporated a new social force into the state structure. Several factors contributed to the failure of the LTTE, including national and international factors. National factors can be highlighted as centralised leadership of Prabhakaran and his inadequate understanding of strategy, mutiny within the LTTE (e.g. Karuna's defection), defection of the political wing of the LTTE, strong state leadership and security, and inability of the LTTE to engage in effective hybrid warfare. The following international factors also contributed to the defeat of the LTTE: the assassination of exPrime Minister Rajiv Gandhi, post-September 11 change in international politics due to GWOT and the international power balance (China factor).

The military victory, which the state of Sri Lanka achieved over the LTTE in 2009, marked a crucial turning point in the political history of the country because it led to the end of the civil war that had raged for over 26 years (Hoglund \& Orjuela, 2011). Migdal (1988, 1994, 2001a, 2001b, 2004) formed and developed the state-in-society approach in several publications. In these studies, the reasons as to how a powerful social force like the LTTE can be demolished and its domination wiped out were not deeply analysed. The state-in-society approach also does not provide sufficient insights into the post-war state-society relations.

In this contextual change, many observers view that the attempts at secession and consequences of war encourage the state and society to address the group rights of ethnic minorities and move forward to state reconstitution by introducing inclusive policies (Marcelline \& Uyangoda, 2013). Contrary to this observation, certain circumstances have led to controversy; that is, the end of the war between the Sri Lankan state and the LTTE further complicated stateminority relations. Consequences of the 9/11 terrorist attack on the United States and its counter agenda, the Global War on Terrorism were the primary influential factors for the state's unexpected victory over the LTTE. Thus, the impact of the post-9/11 international agenda destroyed the formidable social force that contested with the state for the formation of a separate state to safeguard the Tamil minority. This defeat has apparently weakened the Tamils and strengthened the state during the post-war period, allowing it to hamper all kinds of attempts to find a fair resolution to the ethnic issues. In the process, the demand of the Tamil minority for inclusive policies was ignored by the state and they were relegated to a weak position.

In the post-war period, former Sri Lankan President Mahinda Rajapaksa appointed the Lessons Learnt and Reconciliation Commission (LLRC) on $15^{\text {th }}$ May, 2010. ${ }^{7}$ However, the overall implementation status of the LLRC's recommendations have been disappointing. The critical move of the state after the war indicates that it has not learnt the lessons of the war and its consequences to reconstitute itself when rebuilding Sri Lanka. The strong post-war government dedicated itself to strengthening the centralised unitary state through various activities. However, the existing literature indicates an attempt to consolidate the unitary state and establish a new political dynasty under President Mahinda Rajapaksa and his extended family, a factor that weakens democracy (Goodhand, 2012).

\footnotetext{
${ }_{7}^{6}$ Defined by Migdal as the possibility of 'state incorporation of existing social forces'.

${ }^{7}$ The commission was appointed to investigate the facts and circumstances regarding the failure of the Cease Fire Agreement that was operational from $21^{\text {st }}$ February 2002. The commission also had to examine the sequence of events that followed thereafter up to $19^{\text {th }}$ May 2009 and the lessons that should have been learnt from those events. Several issues were looked into, in order they may be implemented to prevent any recurrence of misunderstandings in the future and to promote further national unity and reconciliation among all communities (LLRC, 2011; Ratwatte, 2012). The LLRC clearly states that devolution of power is needed and there is no doubting it (LLRC, 2011).
} 
As part of society, the Tamil minority has learned good lessons from the war; that is, another war and secession is not the solution. The consensus of the majority community is needed to reach a solution via a state reconstitution in post-war Sri Lanka. As a result of this change in attitude, the Tamil minority became willing to reach a political compromise with the majoritarian state in contemporary Sri Lanka. For this purpose, the main Tamil party, the Tamil National Alliance (TNA), is seeking the support of the international community and Tamil diaspora. Both these groups are viewed in a negative manner by the majority community who oppose the Tamils' intention to create a federal system. Alternatively, other forces (e.g., Eelam People's Democratic Party - EPDP), ${ }^{8}$ the forces within the TNA, and the Tamil diaspora-based community, continue to disturb the processes and efforts needed for state reconstitution.

Consequently, Tamil Diaspora groups managed to draw wide international attention towards the Sri Lankan government's military offensive that defeated the LTTE. These efforts influenced Western governments and international human rights organisations to file human rights charges against the Sri Lankan government (Tamilnet, 2010, cited in Bandarage, 2012).

\section{Findings and Discussions (Critical Review of the Theory)}

State-in-society theory is a powerful means for understanding a state by studying the interactions between state and society. As a theory of political science, it conducts political inquiry by adopting a scientific approach. However, this theory does not consider a 'militant group' as a social force in the process of analysing the state and society's mutual transformation and (re)constitution for political domination. The key categories of analysis show how militant social forces attempt to transform and reconstitute the existing unitary state as supported by the findings of the study. However, the statein-society theory does not provide an analysis of how militants act as a social force and participate in the state construction process. This theory prioritises the informal and formal social forces (e.g., Senegal's patron-client networks or friendship groups and old-boy networks in other societies and businesses and churches) that engage with the state on behalf of the society. Different forms of forces, particularly how militant social forces form and how they deal with the state in the best interests of a segment of the society, are not studied. A plural or multi-ethnic society can lead to state-minority contestations and civil wars. Logically, image and actual practices of a state may introduce policies of exclusion of minorities from the state system, and militants may then contest the state and fight for inclusive policies, state reconstitution (from unitary to federal) and even the constitution of a separate and new state within the territory. However, the militants also act as a social force.

State-in-society theory posits that actual states are shaped by two elements, namely, image and practices. In the definition here, the image of the state is that of a dominant, integrated, autonomous entity that controls all rule-making in a given territory, either directly through its own agencies (practices) or indirectly by sanctioning other authorised organisations (e.g., businesses, families and clubs) to formulate certain circumscribed rules. ${ }^{9}$ Migdal studies image and practices of the state from the ideas of Shils and Weber ${ }^{10}$ and offers a new definition of the state. Migdal's definition shows the picture of contemporary states in the world, particularly the newly-independent states, but the context of Sri Lanka is different from that of others. In particular, the post-

\footnotetext{
${ }^{8}$ It is a legitimate Tamil political party in Sri Lanka and its leader is Douglas Devananda, a Member of Parliament who served as minister of social services and social welfare and later as minister of traditional industries and small enterprises during the Mahinda Rajapaksa regime. But, the EPDP was originally formed as a militant social force among Tamils but it later joined with the state of Sri Lanka and worked in a paramilitary capacity for several years.

9 'Image implies perception. Here, perception of the state is by those inside and outside its claimed territory as it is the chief and appropriate rule maker within its territorial boundaries' (Migdal, 16, 2001). Thus, the state is a supreme body that controls informal and formal social forces within its territory according to its rules.

10 In Shils, Center and Periphery (p.74), Weber writes, 'The right to use physical force is delegated to other institutions or to individuals only to the extent to which the state permits it'. The state is considered the sole arbiter of the 'right' to use violence according to Max Weber (p.78) (Migdal, 16, 2001).
} 
independent state of Sri Lanka was constructed as a strong unitary model and the image of the state controls and alienates Tamil speaking minorities directly and indirectly through policies of exclusion from certain areas like education and the public service that come under the state structure, and which are dominated by the majority. Policies that favour the Sinhalese majority as part of the unitary state structure as well as the actual practices of the state result in discrimination in the entire country. With such state policies, the minority segments of society in Sri Lanka felt they were being alienated by the majoritarian state and so formed social forces that demanded a reconstitution of the state into a federal structure. In due course, the Tamil youth lost confidence in their political elites as they were convinced they could not recapture the Tamil rights that were lost through the policies of exclusion. As a result, they formed several Tamil militant social forces that operated separately.

The state introduced the Prevention of Terrorism Act and the Emergency Rules and Regulations to control these militant social forces. However, the LTTE became a strong militant social force amongst the Tamil militant groups and challenged the autonomy and central control of the state. Several studies reveal that the LTTE operated a de-facto state, controlled substantial territory and established other elements of a state such as a police force, legislation and judiciary. Moreover, the administration of the LTTE served the Tamil people in its control area with actual services through its state institutions and bureaucracy. By maintaining the military balance or stalemate situation, the LTTE was able to bring the state of Sri Lanka to the negotiation table with some persuasion from international facilitators. Both the state and minority social forces then agreed to work towards a federal solution. Thus, the LTTE was able to weaken the Sri Lankan state. This has raised an interesting argument. In particular, Migdal's state-in-society theory clearly worked in Sri Lanka because the state and society mutually transformed and attempted to (re)constitute each other. However, Migdal does not consider militants as a social force in his theory. In the context of Sri Lanka, militant social forces played a role equal or similar to Migdal's social forces. Therefore, the present study expands the state-in-society theory through it empirical analysis that 'militant social force(s)' can be considered as a social force, which is contrary to the assumptions of the state-in-society theory. In different parts of the world, several militant social forces are challenging the image and actual practices of the state. To understand the state properly, the social forces that play important roles on behalf of the minority or a part of the society should be studied.

If the civil war ended via the influence of national and international factors, then the result might be a one-sided military victory. The weakening of the side defeated in the war could have been possible. The state penetrates society and destroys the militant social force. ${ }^{11}$ In this situation, post-war state and society relations are ignored by the state. This study provides an insight into these issues and attempts to expand Migdal's state-in-society theory through its empirical findings.

Through the defeat of the strong social force, the state became much stronger, whereas the minority society became much weaker. The weakened society could no longer contest the image of the strong state and achieve success in the transformation and reconstitution of the state. In this situation, the strong state reintroduced policies of exclusion and alienated the Tamil minorities further from the state system. Rajapaksa was a skilful leader who formed a post-war strong state along with his ruling elites. The state's strongman Rajapaksa used his popularity (gained due to victory over the LTTE) as a propaganda strategy to win the second election in 2010, and the masses obliged by extending support to Rajapaksa and his UPFA coalition. Included in his coalition were radical social forces from the majority community that played an instrumental role in his electoral victory and the formation of a strong state, which denied the existence of a state-minority contestation in Sri Lanka and were opposed to inclusive policies. This study shows that in the postwar context of Sri Lanka, the strong state rapidly built up its capability to penetrate weakened Tamils and regulate their social relationship in the Northern and Eastern provinces in which the

\footnotetext{
${ }^{11}$ State-in-society theory posits that the state's penetration leads to the destruction, co-option or subjugation of local society, followed by the state's domination. The theory also explains that other draconian measures may nullify or destroy any dominating local social forces.
} 
LTTE had ruled strongly for so many years.

In spite of the loss, the remaining and newly-formed social forces continue to contest the state for inclusive policies with the support of the Tamil diaspora. However, these powerless forces cannot influence the state. This situation has been ignored by the state-in-society theory. In this backdrop, the international community could have intervened in this matter and insisted that the state introduce inclusive policies to avoid another major contestation. Unfortunately, the international community did not employ skilfully the issue of violation of international laws during the final stages of the war and intervene in Sri Lanka. The international community failed to safeguard the weakened minority. Therefore, state-in-society theory should analyse the process of state and society relations in the post-civil war states.

\section{Conclusion}

The purpose of this study is to understand the relevance and applicability of Migdal's state-insociety model to the Sri Lankan situation. The state-in-society theory attempts to explain how the formal and informal social forces interact with the state to maintain and protect the interests of society. Only the functioning of social forces that were working with the state on behalf of the society were studied by Migdal, while the militant forces that tended towards a violent approach to mould society were left out. The objective of this study is to expand the frontiers of the state-insociety theory by assuming that a militant force can also be regarded as a social force, though such an idea does not fit within the fundamental concept of the state-in-society theory. The need to bring in militant social forces into this theory has arisen because of the many armed groups that have been emerging in various countries of the world, challenging the conventional order and trying to change the customary practices of states. In order to acquire a good understanding of the workings of the state, its interactions with the social forces that represent and speak for the minorities or other segments of society must be investigated closely. This study shows that after the civil war ended the position of the Tamils became very weak and the government became very strong. The Northern and Eastern provinces that had been fully under the control of the LTTE for a long time came to be dominated by the government, which began to maintain a heavy military presence in those areas. However, the rather limited social forces still remaining in the post-war period need to stay calm and cooperate with the state so that they may be able to regain the strength of their society. There is also the need to conduct further study on the constantly changing relationship between the state and society.

\section{References}

Abeysekera, C. (1985). Ethnic representation in higher state services. In D. Bell (Ed.), Ethnicity and social change. Colombo, Sri Lanka: Social Scientists' Association.

Bandarage, A. (2010). The separatist conflict in Sri Lanka: Terrorism, ethnicity, political economy. Colombo, Sri Lanka: Vijitha Yapa.

Bandarage, A. (2012). Towards peace with justice in Sri Lanka. Indian Quarterly, 68(2), 103-118. Los Angeles, USA: Sage.

Bastian, S. (2009). The politics of land reform and land settlement in Sri Lanka. Articles. Retrieved from http://www.sunilbastian.com/content_images/1401161701Politics\%20of\%20Land\%20Reform\%20in\%20Sr i\%20Lanka.pdf

De Silva, K.M. (2005). A History of Sri Lanka. Sri Lanka: Vijitha Yapa Publications.

De Silva, C.R. (1997). Sri Lanka: A History. (2 ${ }^{\text {nd }}$ ed.). New Delhi, India: Vikas.

De Silva, K.M. (1981). A History of Sri Lanka. Delhi, India: Oxford University Press.

Fazil, M.M. (2004). Muslim factor in Sri Lankan ethnic conflict. In Frerks, Georg \& B.Klem (Eds.), Dealing with diversity: Sri Lankan Discourse on Peace and Conflict, The Hague, Clingendael: the Netherlands Institute of International Relations.

Fazil, M.M. (2018). State - minority contestations in post-colonial Sri Lanka. (Doctoral thesis), University of Malaya, Malaysia.

Flynn, K. (2011). The Liberation Tigers of Tamil Eelam: A revolution in military affairs. (Unpublished Master's Thesis) The Faculty of the Graduate School of Arts and Sciences of Georgetown University. 
Goodhand, J. (2012, January/February). Sri Lanka in 2011 consolidation and militarization of the post-war regime. Asian Survey, 52(1), 130-137. University of California Press.

Halliday, F. (1975). "The Ceylonese Insurrection". In Blackburn \& Robin. Explosion in a Subcontinent: India, Pakistan, Bangladesh, and Ceylon. Harmondsworth, England: Penguin.

Heidorn, C. (2006). Sri Lanka: Planting seeds for peace, ESCP-EA. Paris, France: Etude de Sciences Sociales et Humanités.

Hoglund, K. \& Orjuela, C. (2011). Winning the Peace: Conflict prevention after a Victor's Peace in Sri Lanka. Contemporary Social Science, 6(1), 19-37.

International Crisis Group [ICG]. (2006). Sri Lanka: The failure of the peace process. Asia Report No. 124.

Kearney, R.N. (1967). Communalism and language in the politics of Ceylon. Durham, USA: Duke University Press.

LLRC (2011). Report of the commission of inquiry on lessons learnt and reconciliation. Retrieved from http://slembassyusa.org/downloads/LLRC-REPORT.pdf

Marceline, S. \& Uyangoda. J. (2013). Post-civil Sri Lanka: Dilemmas of state reform. In J. Uyangoda (Ed.), State reform in Sri Lanka: Issues, directions and perspectives. Colombo, Sri Lanka: Social Scientists' Association.

Migdal, J.S. (1994). State power and social forces: Domination and transformation in the third world. Cambridge, UK: Cambridge University Press.

Migdal, J.S. (1998). Strong societies and weak states: State-society relations and state capabilities in the third world. Princeton, USA: Princeton University Press.

Migdal, J.S. (2001a). State in society: Studying how states and societies transform and constitute one another. New York, USA: Cambridge University Press.

Migdal, J.S. (2001b). Through the lens of Israel: Explorations in State and Society. Albany, USA: State University of New York Press.

Migdal, J.S. (2004). Mental maps and virtual checkpoints: Struggles to construct and maintain state and social boundaries. In J. S. Migdal (Ed.), Boundaries and belonging: States and Societies in the Struggle to Shape Identities and Local Practices. New York, USA: Cambridge University Press.

Nieto, W.A.S. (2008). A war of attrition: Sri Lanka and the Tamil tigers. Small Wars \& Insurgencies, 19(4), 573587.

Orjuela, C. (2004). Civil society in civil war: Peace work and identity politics in Sri Lanka. Goteborg, Sweden: Goteborg University.

Rabushka, A. \& Shepsle, K. (1972). Politics in plural societies: A History of democratic instability. Columbus, USA: Merril.

Ratwatte, C. (2012). Darusman, LLRC, Petrie conundrum and the trial by media. Retrieved from https://www.colombotelegraph.com/index.php/darusman-Ilrc-petrie-conundrum-and-the-trial-by-media/

Senake, B. (1985). The peopling of Sri Lanka. Ethnicity and social change. Colombo, Sri Lanka: Social Scientists' Association.

Tamilnet. (2010, December 17). Canadian Tamil submission to UN focuses on international investigation. Retrieved from http://tamilnet.com/art.html?catid=13\&artid=33239\&fromNewsdog=1\&utm_source=NewsDog

Vittachi, T. (1959). Emergency '58: The story of the Ceylon race riots. London, UK: Andre Deutsch.

White, A. (2013). The everyday life of the state: A State in society approach. London, UK: Center for Global Studies. University of Washington press. 